\title{
Why Do Food Prices Increase?
}

\author{
MICHAEL T. BELONGIA
}

VER the past decade economists have devoted much research effort to identifying factors that influence the direction and magnitude of changes in food prices. Under the widely-accepted belief that "food prices rose faster than nonfood prices during the 1970 s, "many have attempted to identify the unique characteristics of food products and their marketing system that have caused food prices to rise faster than the general rate of inflation. ${ }^{1}$ These studies typically concluded that market concentration and increases in the costs of assorted inputs were the chief causes of increases in retail food prices.

Not all analysts share these views, however. First, there is some disagreement concerning whether food has, in fact, become relatively more expensive in recent years. Second, recent empirical research has found that increases in food prices are more directly related to the monetary policy of the Federal Reserve than they are related to unique marketing practices of firms in the food industry. Thus, contrary to the predominant view, these arguments contend that increases in food prices, on average, share the same path as that followed by other prices.

The following discussion attempts to clarify some of these issues. After several basic economic concepts are defined, a statistical analysis of the data is conducted. The evidence suggests that virtually all of the long-run increases in food prices can be explained by past rates of growth of the money stock. Conversely, the discussion in the article's final section indicates that predic.

\footnotetext{
'See, for example, R. MeFall Lamm, "Prices and Concentration in the Food Retailing Industry," Journal of Indastrial Economics (September 1981), pp. 67-78; Larry E. Salathe and William T. Boehm, Food Prices in Perspectice: A Summary Analysis, Economics, Statistics and Cooperatives Service (U.S. Department of Agriculture 1978); and R. McFall Larm and Paul C. Wescott, "The Effects of Changing lnput Costs on Food Prices," Anerican Journal of Agricultural Economics (May 1981), pp. 187-96.
}

tions of competing theories often are contradicted by actual events.

\section{RELATVIT VS. NOMMAL PRTCES}

The first step necessary in a discussion of price changes draws the distinction between relative and nominal prices. Put most simply, nominal (or money) prices are the actual, dollar-denominated prices at which goods are exchanged; for example, a newspaper's nominal price is 25 cents. A relative price, however, expresses the cost of a good in terms of other goods, not in terms of money. That is, if a book's nominal price is $\$ 2$, the relative price of a newspaper - relative to a book - is $1 / 8(\$ 0.25 \div \$ 2.00=1 / 8)$. This shows that the newspaper is "worth" one-eighth of a book.

The importance of this distinction is more than numerical in nature. There is a crucial economic distinction between nominal and relative prices. Changes in relative prices reflect changes in the rate of exchange between goods caused by relative changes in the supply and/or demand for goods; changes in nominal prices reflect changes in the rate of exchange between goods and money associated with changes in the supply and/or demand for money. For example, under a neutral inflation, in which all nominal (money) prices increase at the same rate, a 20 percent increase in the price of newspapers to 30 cents would be matched by a 20 percent increase in the price of a book to $\$ 2.40$ (1.20 $\times \$ 2.00=\$ 2.40$ ). This equal percentage increase in all money prices is nentral because relative prices are unaffected; that is, with a neutral 20 percent inflation, the relative price of a newspaper is still $1 / 8(\$ 0.30 \div$ $\$ 2.40=1 / 8$ ) of the book.

The distingtishing feature of an equal percentage change in all nominal prices is that it has no long-run impact on economic activity; that is, it does not change 
the allocation of resources between newspapers and books. ${ }^{2}$ In other words, when all prices - including incomes - are rising at equal rates, relative prices remain unchanged. In this instance, an individual who allocates fixed proportions of his income to newspa pers, books, food and housing is unaffected by a neutral inflation: even though all prices rise by 10 percent, these changes are offset by a 10 percent increase in income. Nominal price changes of this nature share a one-to-one correspondence with past rates of growth of the money stock. ${ }^{3}$

Conversely, relative price changes for individual products both result from, and contribute to, changes in economic relationships. For example, if an increase in demand doubled the price of newspapers from 25 cents to 50 cents, an individual who purchased newspapers would adjust his spending patterns to reflect this increase. That is, if one person previously had purchased four newspapers per week for $\$ 1(4 \times \$ 0.25)$ out of a $\$ 100$ weekly income, there would be $\$ 99$ per week to spend on other items. When the newspaper price rises to 50 cents, the four newspapers cost $\$ 2$ and only $\$ 98$ remains for other purchases. The change in the relative price of newspapers forces this individual to reallocate the $\$ 100$ of weekly income: either the purchase of newspapers or other goods must be reduced by $\$ 1$.

The issue of changes in food prices also can be reduced to this simple dichotomy between movements in relative and nominal prices. Analysts who believe

\footnotetext{
${ }^{2}$ Rational expectations theorists may argue that real economic activity will be affected in the short run anless price changes are forecast perfectly, e.g., Robert E. Lucas, Jr., "Expectations and the Neutrality of Money," Journal of Economic Theory (April 1972), pp. 103-24. The present anatysis also ignores the effects of factors like a progressive tax structure, usury laws and other impediments that prevent or complicate a complete indexation of this type of price change. For purposes of illustration, however, this simple example is intenked only to draw a distinction between relative and nominal prices.

The linkage between past growth rates of the money stock and the carrent rate of inflation has been established in a number of studies. Among these are: Peter I. Berman, Inflation and the Money Supply in the United States, 1956-1977 (Lexington Books, 1978); Yash P. Mehra, "An Empinical Note on Some Monetarist Propositions," Southern Econonic Journal July 1978), pp. 154-67: Robert E. Lucas, "rwo Ilustrations of the Quantity Theory of Money," American Economic Rectew (December 1980), pp. 1005-14; Denis S. Karnosky, "The Link Between Money and Prices," this Review (June 1976), pp. 17-23; Keith M. Carlson, "The Lag from Money to Prices," this Review (October 1980), pp. 3-10, and John A. Tatom, "Energy Prices and Short-Run Econonic Perfomance" this Re. view (January 1981 ), pp. 3-17.

Further discussion of the distinction between inflation and changes in relative prices can be found in Lawrence $S$. Davidson, "Inflation Misinformation and Monetary Policy," this Reciew (June/July 1982), pp. 15-26.
}

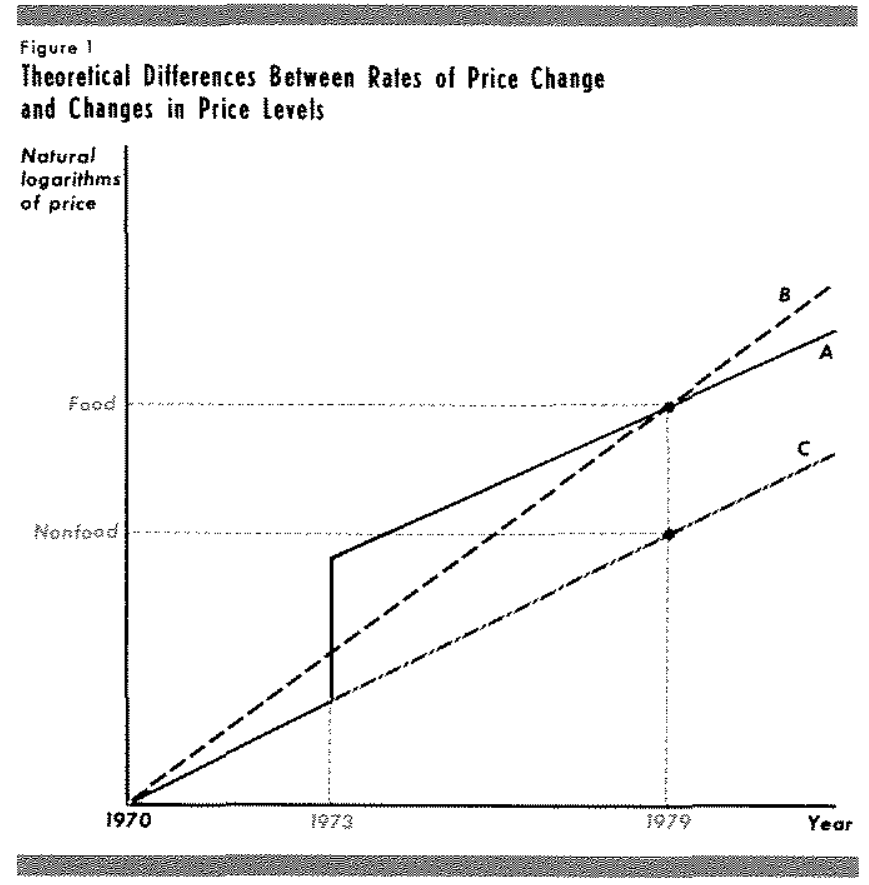

food prices have risen faster than nonfood prices are arguing that shifts in the relative supply and demand conditions for both food and nonfood products have resulted in a net increase in the relative price of food. Conversely, those who argue food prices grew at the same rate as other prices believe that most of the recent changes in food prices can be linked directly to the high rate of money growth that existed over this period. The distinction between these views is illustrated in the graphical analysis that follows.

\section{ALTERNATTE INTERPRETATIONS OF HISTORICAL DATA}

Those who argue that food prices increased at a relatively faster rate than nonfood prices in the $1970 \mathrm{~s}$ (see footnote 1) base their conclusion on the observation that, over this period, the food component of the Consumer Price Index (CPIF) increased by 87 percent compared to a 66 percent increase for the nonfood component (CPINF), Although these statistics are correct technically, they are based on total increases for the 10-year period. That is, the 87 percent increase for CPIF is determined by constructing the simple difference of index values for December 1969 and December 1979. This simple calculation of price change, however, fails to distinguish between changes in price levels and average rates of price change.

To see the problem with this type of calculation, consider figure 1 . Lines $A, B$ and $C$ represent different growth paths for the food and nonfood components of 
the CPI. The horizontal lines drawn at levels denoted by Food and Nonfood indicate, respectively, the 87 and 66 percent increases these indices registered during the 1970 s.

Although lines A and B both are consistent with the actual 87 percent increase in food prices that occurred during the $1970 \mathrm{~s}$, the differences in their slopes imply very distinct economic interpretations of this statistic. On one hand, lines $B$ and $C$ are compatible with the popular view that food prices increased at a relatively faster rate over this 10-year interval. That is, since 1970 , the slope of line B, which represents a constant rate of growth for food prices, has been greater than the slope of line $\mathrm{C}$, which depicts the growth rate of nonfood prices. This suggests that fundamental differences in production and marketing processes established different long-run growth rates for food and nonfood prices in the 1970s. Or, because the difference in slopes appears to be a permanent structural difference, lines $B$ and $C$ also carry the implicit hypothesis that food will continue to increase in value, relative to nonfood products.

Lines $\mathrm{A}$ and $\mathrm{C}$ also are consistent with the historical data but do not imply any fundamental changes in the relative growth rates of food and nonfood prices. Instead, line A illustrates the effect of certain events in 1973 on the relative level of food prices. But, aside from this isolated change caused by relative shifts in world food supply and demand relationships, lines A and C have the same slope. That is, with the exception of 1973's adjustment in relative prices, both food and nonfood prices, on average, have grown at the same rate both before and since 1973. Therefore, lines A and $C$ are consistent with the nominal price changes that occur during a neutral inflation. Or, stated differently, the slopes of lines $\mathrm{A}$ and $\mathrm{C}$ depict the shared increases in all nominal prices that are associated commonly with past rates of growth of the money stock.

These theoretical relationships can be compared to plots of actual price changes shown in chart 1 . In general, these plotted lines reflect the same qualitative results suggested by lines $\mathrm{A}$ and $\mathrm{C}$ in figure 1 . The level of food prices did increase, relative to nonfood prices, in 1973 but, after the effects of this relative price change dissipated, food and nonfood prices tended to follow the same trend rate of growth. In fact, declines in the relative price of food in every year since 1978 have caused the food price and the nonfood price lines to converge. Or, rather, the large increase in the relative price of food during 1973-74 has been offset by five consecutive declines in relative food prices since 1978 .

\section{Food Prices and Woney Crower}

The distinctions of the two preceding sections suggest that the problem for an analysis of food prices is to specify a statistical model that can distinguish between changes in relative and nominal prices or, alternatively, between the types of change depicted by lines $A$ and $B$ in figure 1 . One such model can be specified as:

$$
\begin{aligned}
\text { CPIF }= & a+\sum_{i=0}^{4} b_{j} \times \dot{M}_{t-i}+\sum_{j=0}^{1} d_{j} \times \dot{y}_{t-j}+\sum_{k=0}^{1} g_{k} \\
& \times \dot{R} P_{t-k}+h \times Z_{i}+q \times Z_{2}+e_{t},
\end{aligned}
$$

where CPIF is the CPI for food; $M$ is the narrowly defined money stock, Mi; $y$ is real GNP; $R P$ is the ratio of the Producer Price Indexes for the "food" and "nonfood" groups; ${ }^{*} Z_{1}$ and $Z_{2}$ are $0 / 1$ dummy variables for phases I-II and phases III-IV, respectively, of Nixon administration price controls; b, d, g, h and $q$ are estimated coefficients; $t$ indicates time (quarterly intervals, 1960-82); and $e_{t}$ is a model error term. Dots over variable names indicate data measured in growth rates. All data are seasonally adjusted.

The reasoning behind this model of food price behavior derives from the basic considerations of figure 1 . and the discussion of relative versus nominal prices. ${ }^{5}$ Because we know any observed change in food prices is likely to be apportioned in some manner between changes in relative and nominal values, a model of price change must include variables associated with general inflation and with changes in product supply demand relationships. Therefore, the model includes past growth rates of the money stock to account for that portion of changes in food prices that is associated with general inflation. Changes in the growth rate of real GNP are included to represent a cyclical effect on prices not captured by money growth. That is, if the equation of exchange is rewritten as: $\overrightarrow{\mathbf{P}}=\dot{M}+\dot{V}-\dot{y}$, then, for a given rate of increase in money and a given M1 velocity, a higher rate of real income growth will tend to be associated with a slower rate of nominal price increase. Therefore, the signs on coefficients $d_{j}$

\footnotetext{
"The actual commodity groups are the Producer Price lnktexes for "all fam foods and feed" and "all ind ustrial commonities" respectively; these groups represent, essentially, at "food" and "nonfood" division of the PPI.

${ }^{3}$ This same basic model estimated with monthly data, and a more detaled explanation of its theoretical support is fond in Michael T. Belongia and Richard A. King "A Monetary Analysis of Foud Price Deteminaton." American Journal of Agricultural Economics (February 1983), pp. 131 -35.
} 


\section{Chart 1}

Actual Movements in Food and Nonfood Prices

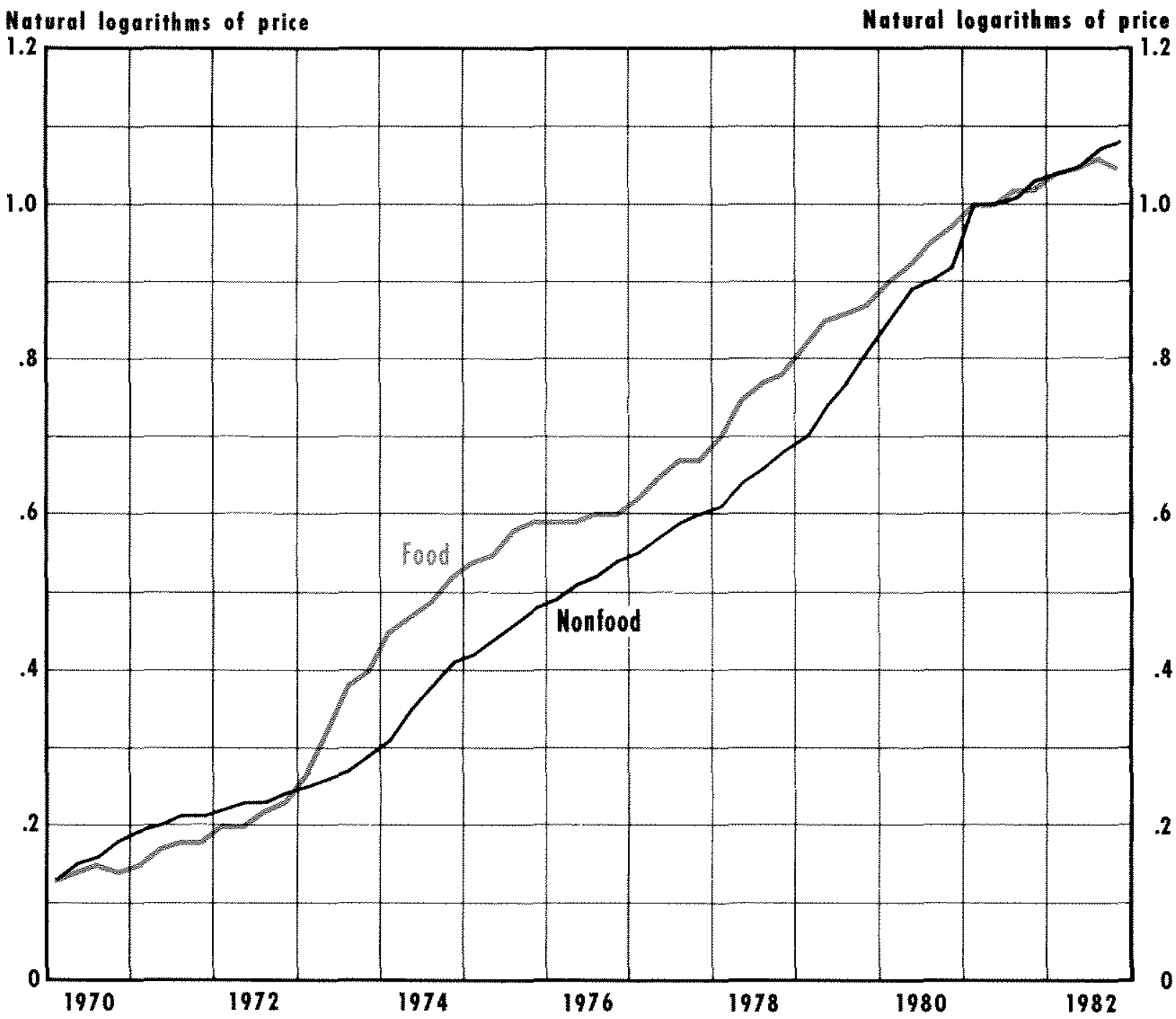

11 Data are from Consumer Price Indices.

are expected to be negative. Changes in basic food supplies are represented by a proxy of changes in the growth rate of relative food prices at the producer, or wholesale, level. The effects of official price controls from August 1971 through January 1974 are represented by variables $Z_{1}$ and $Z_{2}$. Together, these variables encompass the sources and types of price changes discussed earlier.

This model implies several specific hypotheses. First, a one-to-one relationship between past rates of money growth and nominal prices would be supported by a test of the full impact of all current and past values of $\mathrm{M}$ on CPIF; the specific hypothesis to be tested is:
(2) $\sum_{i=0}^{4} b_{i}=1$,

or that an $\mathrm{X}$ percent increase in the rate of money growth over the most recent five quarters will cause a similar $X$ percent change in the current growth rate of nominal food prices. ${ }^{6}$

${ }^{6}$ The postulated lag length is considerably shorter than the 20 quarter lag between money and prices reported in other studies. The reason for this difference is the choice of price index for the model's dependent varable. Because supply and demand finctions for food products tend to be more inelastic than those assocated with other goods, changes in the supply of, or demand for food will tend to affect prices more quickly than is typical in other markets. 
Another hypothesis concerns changes in relative prices. Here, the concern is the net impact of a change in the growth rate of real income and a change in relative producer prices. In addition to the effect of real activity on nominal price growth shown via the equation of exchange, a change in product supplies also could affect CPIF by changing the relative price of food. Because these effects are expected to be offsetting, the hypothesis test takes the form:

$$
\text { (3) } \sum_{j=0}^{1} d_{j}+\sum_{k=0}^{1} g_{k}=0 \text {. }
$$

Finally, it is interesting to know whether general price controls during the $1971-74$ period had significant effects on food prices, which were treated differently than other controlled commodities. If controls were effective, the coefficient on $Z_{1}$ should be negative and the coefficient on $Z_{2}$, when controls were gradually relaxed, should be positive.

The ordinary least squares results in table 1 support these propositions. The hypothesis test for equation 2 suggests that the net impact of money growth is not significantly different from one; the rate of money growth over the current and past four quarters causes an equal change in the subsequent growth rate of retail food prices. ${ }^{7}$ Therefore, except for transitory short-run deviations, the observed changes in retail food prices have been changes in their nominal values, not in their relative prices. Changes in food prices are related most closely to changes in the growth rate of the money stock. $^{8}$

This result is supported by the tests of other a priori hypotheses. The net effect of changes in the growth rates of real income and relative producer prices is shown to be zero, indicating that relative food prices have not changed significantly over this sample period. This provides further support for the notion that food prices have increased, on average, in a fashion similar to general inflation. Therefore, as the discussion in the next section indicates, studies based only on factors affecting supply and demand conditions are in substantial disagreement with the historical data: if relative prices have not changed appreciably, studies based on factors that shift supply and demand functions will not

\footnotetext{
${ }^{7}$ Although the coefficients on the third and fourth lags of money growth are nonsignificant individually, an F-test on their joint significance suggests these terms should be retained in the model.

This relationship also appears to be stable over time. The model also was estimated over $1960-72,1970-82$ and $1973-82$ subsamples and, in each case, the growth rates of the money stock and food prices shared an approximate one-to-one correspondence.
}

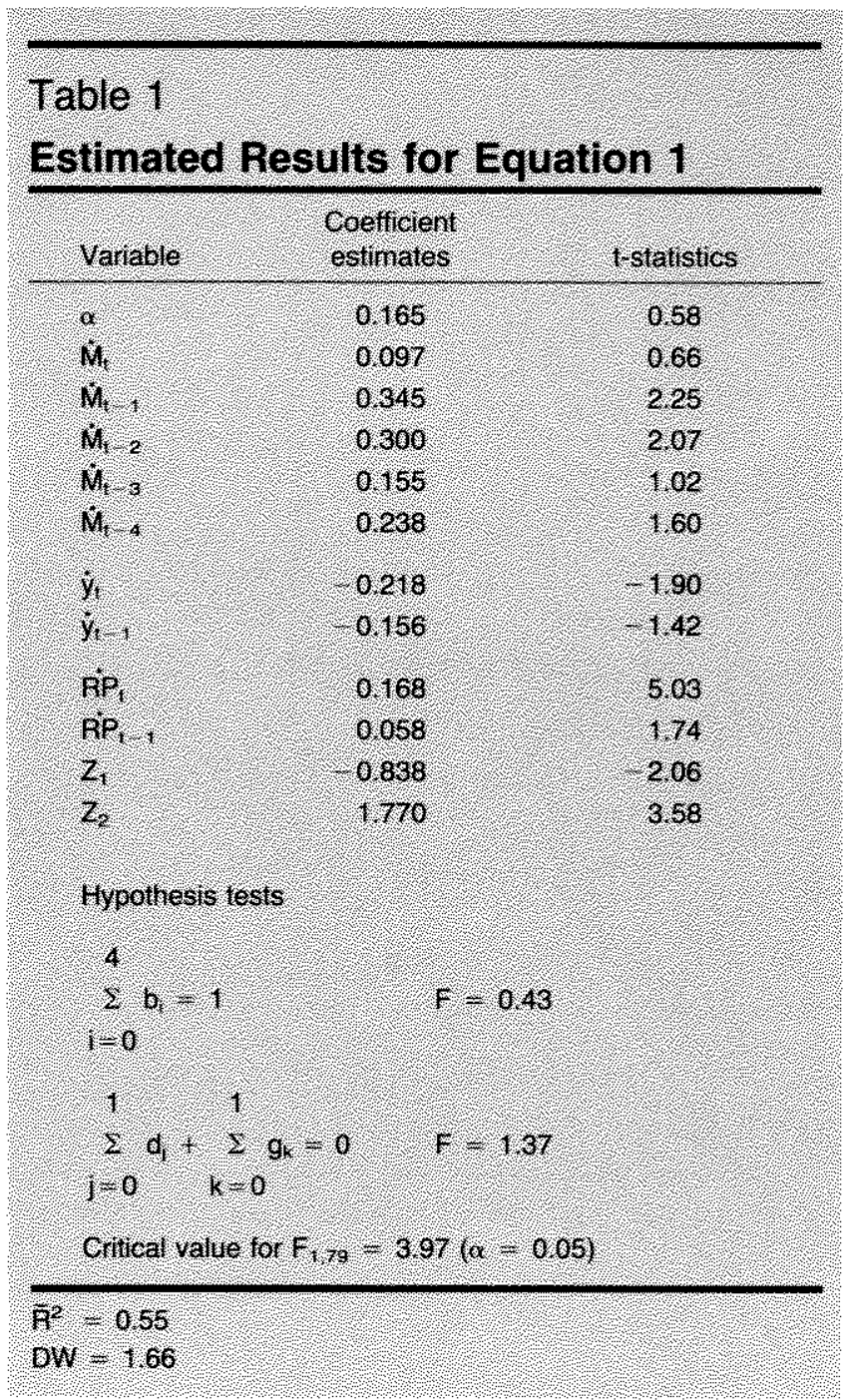

present accurate descriptions of observed price changes.

Finally, the coefficients on price control variables are of the expected sign. From August 1971 through the end of 1972, when controls were applied most stringently, they apparently did reduce the rate of increase in reported food prices. ${ }^{9}$ Then, from 1973 through 1974 , controls were relaxed gradually and food

\footnotetext{
This does not imply, however, that controls were an effective antiminflationary policy. In fact, although there is an observed statistical effect on food prices in these results, controls themselves were abandoned, in large part, because of the resonrce allocation problems they caused. That is, controls masked changes in relative prices that give signals to producers concerning their ontput decisions. Consider, for example, that higher food prices are caused by product shortages. Higher prices, however, will tend to encourage increased production and, in the longer run, increased production will cause lower prices. Therefore, if price controls limit or forbid price increases, their negative impact on production incentives will exacerbate the shortage-high price conditions.
} 
prices began to increase at a faster rate. These results again support expected price behavior during this period.

The general conclusion of this analysis might be seen more clearly by constructing a comparison of the effects of $\dot{\mathrm{M}}, \dot{\mathrm{y}}$ and $\dot{\mathrm{R}} \mathrm{P}$ on the growth rate of retail food prices. After adjusting CPIF for the effects of the model's intercept, $Z_{1}$ and $Z_{2}$, it is possible to write:

(1') $\overline{\mathrm{CPIF}} \simeq \sum_{i=0}^{4} b_{i} \times \overline{\dot{M}}+\sum_{j=0}^{1} d_{i} \times \overline{\dot{y}}+\sum_{k=0}^{1} g_{k} \times \overline{\dot{k P}}$

where the bars over variable names indicate their average, or mean, values. By summing the coefficient estimates as indicated and inserting the data means, equation I' can be rewritten as:

$$
\begin{aligned}
1.280 & \simeq(1.136 \times 1.32)+(-0.374 \times 0.77) \\
& +(0.226 \times(-0.23))
\end{aligned}
$$

or,

$$
\text { (5) } 1.280 \simeq 1.500-0.288-0.052 \simeq 1.160 \text {. }
$$

In this form, an evaluation of the model's results at the data means indicates that $\mathrm{ML}$ and CPIF share an approximate one-to-one correspondence, whereas changes in real activity - over this sample period tend to decrease the relative price of food. Contrary to the popular belief, food price increases would have been larger had it not been for the mitigating effects of real income growth and shifts in relative producer prices.

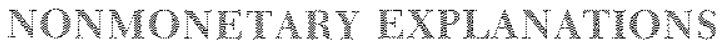 MOR FOOD PRICE MCTELSES:

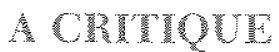

A number of studies have offered alternative explanations for why food prices increase and, further, why they have increased relative to other prices. These explanations include increasing prices for farm products, ${ }^{10}$ farm price support programs, ${ }^{11}$ unioniza-

\footnotetext{
19) See, for cxample, Don Palarlbers, fram and Food Policy Unversity of Nebraska Press, 1980); Albert Eckstein and Dale Heien, "The 1973 Food Price lutation," American foumal of Aaricul. tural Economics (May 1978), pp. 186-96, Rodney C. Kite and Joseph M. Roop, "Changing Agricultural Prices and Their Innpact on Food Prices Under Inflation," Anertican Journal of Agriculfural Economics (Decenber 1981), pp. 956-61; and Lamm and Wescott, "The Efocts of Clanging lnput Costs . . . "

1.1. B. Pem, "Commodity Programs and Lnflation," A therican Journol of Agricultural Economics (Decenber 1979), pp. 889-95.
}

tion of food sector employees ${ }^{12}$ and increased concentration of the food industry. ${ }^{1 / 3}$ The following discussion indicates that these explanations either are unrelated to the trend growth rate of food prices or predict results contrary to observed events.

\section{Prising Input Costs}

One alleged cause of increased food prices attributes observed increases in the CPIs for various food groups to increases in the prices of inputs used to produce finished retail food products. Specifically, some previous studies have found that increases in the nominal costs of raw farm products have led to subsequent increases in the retail prices of foods purchased by consumers. The logic behind this explanation is, essentially, that if the prices of the inputs used to produce food items are increased, those processors and retailers who produce and sell food products also must raise their prices to maintain previous profit margins or avoid losses.

The explanation that rising input costs have caused increases in retail food prices is flawed on an empirical basis, if for no other reason. That is, because the relative prices of major food groups at the producer level declined during most years of the $1970 \mathrm{~s}$, these inputs actually became relatively less expensive for food manufacturers. These declines in relative prices for raw farm products should have put downward pressure on both producers' costs and output prices. Or, other things being equal, these data suggest that food manufacturers should have been able to produce a given quantity of food at lower - and declining - costs. This is an unlikely explanation for increasing retail food prices.

\section{Concentraton Patios and Prices}

Higher concentration ratios for the food industry or relatively higher union membership anong workers in the food industry might explain why food prices are at a higher level than their values under perfect competition. But these structural characteristics of the industry could only cause food prices to rise continuously if it is shown that these monopolistic elements also strengthened continuously over the same period. Institutional arrangements - like union bargaining power and pricing strategies among a few relatively large

\footnotetext{
${ }^{12} \mathrm{R}$. McFall Lamm, "Unionsm and Prices in the Food Retailing Industry," Journal of Labor Research (Winter 1982), pp. 69-79.

${ }^{13}$ Lamnon, "Prices and Concentration . . . ."
} 
firms - usually act in a manner similar to price support programs. That is, some degree of control over pricing decisions - such as a union's ability to secure higher nominal wages for union workers - can act like a price support which raises a commodity's price above its competitive market value. The ability of a union or a highly-concentrated food industry to raise wages or prices to higher levels, however, is not the same as an ability to raise relative wages or prices continuously. Again, there is a necessary distinction between rates of price change and changes in relative price levels.

There are at least two reasons why neither type of market power is likely to explain ongoing price changes. On the one hand, a producer facing a downward-sloping linear demand curve will have an incentive to raise prices until profits are more affected by declining sales than by higher prices. If a firm starts at a position where raising prices is profitable and decides to raise its product's price, the firm will benefit in two ways. The increased price will, ceteris paribus, reduce the quantity sold, which will reduce costs. At the same time, total revenue will increase because the percentage reduction in the quantity sold will be less than the percentage increase in the output price. At some point, where the product's price elasticity is equal to -1 , total revenue will be maximized. At prices above this level, total costs will continue to decline but total revenue also will fall. Therefore, as Batten has explained, price increases beyond some level will result in reductions in marginal revenue (from a smaller quantity sold) larger than the associated decreases in marginal costs (from producing less). ${ }^{1.4}$ In this case, the price increases will reduce profits and, if other firms do not follow the price increases - as traditional oligopoly theory suggests - the firm's market share also will be diminished.

A second counterargument to the alleged relationship between increasing concentration ratios and inflation is found in the reason why an industry becomes more concentrated. Eckard, who found no relationship between concentration ratios and price increases, argues that industries become more concentrated because firms are able to produce at lower cost. ${ }^{15}$ The sequence of events begins with gains in productivity (most notably, labor productivity) that reduce a firm's input costs and allow it to price its

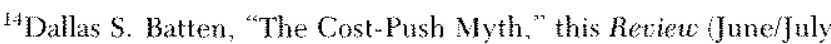
1981), pp. $20-25$.

${ }^{15}$ E. Woodrow Eckard, Jr, "Concentration Changes and lnflation: Some Evidence," Jotrnal of Political Economy (October 1981), pp. 1044-51
}

output below the level charged by competitors. Consequently, more efficient production and lower prices provide an opportunity for this firm to increase sales which, in turn, tends to make its industry more concentrated. This sequence of events - increased productivity and lower input costs ultimately resulting in increased industry concentration - is supported by empirical evidence provided by Peltzman. ${ }^{16}$ The concentration ratio-inflation hypothesis also suffers from its own predictions, however: if these models were correct, actual declines in the relative price of food must imply that the food industry has become less concentrated over this period.

\section{Union Power and Prices}

Similarly, the existence of union bargaining power might explain a higher level of costs for a firm purchasing this type of labor. And, a higher level of costs might be used to explain a higher price level for the products produced by a firm using union labor. For the same reasons used in the previous argument, however, the existence of bargaining power in wage negotiations is unlikely to explain why nominal or relative food prices would rise continutously.

One extension of the sequence by which union power causes higher prices through increased wages is presented explicitly in a model by Moore and implicitly in some food price studies. ${ }^{15}$ The argument presented is that umion wage negotiations and their wage contracts are ongoing processes that result in continuous upward adjustments in nominal wage levels. Further, it is recognized that because wages are just one price among all prices, an increase in the relative price of labor necessarily must be offset by a decline in the relative price of one or more other goods unless the money stock is increased. So, instead of an adjustment of relative prices and wages, the models argue that the Federal Reserve will monitor nominal wage increases and "ratify" them by increasing the money supply. Increases in the growth rate of the money stock will cause inflation, however, and therefore will reduce the purchasing power of wages as product prices increase. This reduction in purchasing power will, it is alleged, set of another round of wage increases to re-establish purchasing power. But, the effort is futile as the money

\footnotetext{
"Sam Peltzman, "The Gains and Losses from Industrial Concentration,"Journal of Law and Economics (October 1977), pp. 229-63.

${ }^{17}$ Basil I. Moore, "Monetary Factors," in Alfred S. Eichner, ed, A Guide to Post-Kotnesian Economics M. E. Sharpe and Co. 1979). pp. $120-38$.
} 
stock grows again and the rate of inflation increases further.

Although a plausible explanation for ongoing increases in food prices, this type of model rests on the assumptions that (a) wage increases established by union power cause increases in product prices, and (b) the Federal Reserve will ratify nominal wage increases with an expansion of the money stock. These are test able hypotheses of real-world behavior. But, an empirical investigation of these relationships rejected the notions that wage increases cause increases in food prices and that the growth rate of the money stock responds to changes in nominal wages. ${ }^{18}$ Therefore, in the one case when unions and food prices might be related, the statistical evidence does not support any direct linkage between wage rates and food prices.

\footnotetext{
${ }^{18} \mathrm{M}$. Belongia, "A Note on the Specification of Wage Rates in Cost-Push Models of Food Price Determination," Southern Journal of Agricultural Economics (December 1981), pp. 119-24.
}

\section{CONCWSTONS}

Changes in food prices since 1970 have been attributed to a variety of sources. These explanations, however, often are based on some confusion over the basic distinction between isolated changes in relative prices and ongoing changes in nominal price levels. After accounting for this distinction, statistical analysis of the data suggest that the recent increases in food prices are increases in nominal price levels that share an approximate one-to-one relationship with past rates of money growth. Competing explanations of food price behavior - unionization, oligopoly power and rising input prices, among others - actually predict results that are contrary to the observed data over this period. Specifically, competing models are based on theories that predict increases in the relative price of food; in fact, the relative price of food has declined over much of the sample period. Relating money growth to food prices appears to offer a better explanation of what actually produced the food price increases during the $1970 \mathrm{~s}$, and what is likely to do the same in the 1980s.

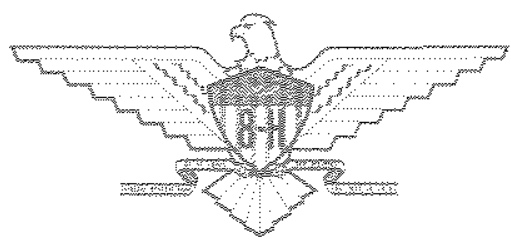

